\title{
Bisperoxovanadium, a phospho-tyrosine phosphatase inhibitor, reprograms myogenic cells to acquire a pluripotent, circulating phenotype
}

\author{
L. Castaldi, ${ }^{*, 1}$ C. Serra, ${ }^{*}, 1,2$ F. Moretti, ${ }^{\dagger}$ G. Messina, ${ }^{\ddagger}$ R. Paoletti, ${ }^{*}$ M. Sampaolesi, ${ }^{\ddagger}$ \\ A. Torgovnick, ${ }^{\dagger}$ M. Baiocchi, ${ }^{\S}$ F. Padula, ${ }^{*}$ A. Pisaniello, ${ }^{*}$ M. Molinaro, ${ }^{*}$ G. Cossu, ${ }^{\ddagger} \|$ \\ M. Levrero, ${ }^{\dagger, \mathbb{I}}$ and M. Bouché ${ }^{*, 3}$ \\ *Department of Histology and Medical Embryology, CE-BEMM and Interuniversity Institute of \\ Myology, University of Rome "La Sapienza," Rome, Italy; ${ }^{\dagger}$ Fondazione A. Cesalpino, CRS Regina \\ Elena Cancer Institute, ${ }^{\ddagger}$ Stem Cell Research Institute, Dibit-H. San Raffaele, Milan, Italy; ${ }^{\$}$ Lab of \\ Hematology, Istituto Superiore di Sanità, Rome, Italy; "Institute of Cell Biology and Tissue \\ Engineering, San Raffaele Biomedical Science Park of Rome, Italy; and "Department of Internal \\ Medicine, University of Rome "La Sapienza," Rome, Italy
}

ABSTRACT Satellite cells are the main source of myogenic progenitors in postnatal skeletal muscle, but their use in cell therapy for muscle disorders is limited because these cells cannot be delivered through circulation and they are rapidly exhausted in severe myopathies. The search for alternative donor cells is ongoing, but none of the candidates so far show all the features required for successful colonization and repair of diseased muscle. In this study, we show that bisperoxovanadium, a phospho-tyrosine phosphatase inhibitor, induces myogenic cells to acquire a gene expression profile and a differentiation potential consistent with the phenotype of a circulating precursors, while maintaining their myogenic potential. These effects are mediated, at least in part, by $\mathrm{NF}-\kappa \mathrm{B}$ activation through the Tyr42-IкB- $\alpha$ phosphorylation, as shown by the expression of the dominant negative mutant form of the p50 NF-кB subunit. Moreover, when bisperoxovanadium-treated cells are injected into the femoral artery of $\alpha$-sarcoglican null dystrophic mice, they are able to circulate and to reach muscle tissue; importantly, they contribute to muscle regeneration, as shown by the expression of $\alpha$-sarcoglican in some fibers. Our observations indicate that bisperoxovanadium, or similar compounds, may prove very valuable to obtain and to expand, from committed cells, multipotent cell populations suitable for gene-cell therapy applications and may help to understand the molecular basis of genome reprogramming and "stem-ness."-Castaldi, L., Serra, C., Moretti, F., Messina, G., Paoletti, R., Sampaolesi, M., Torgovnick, A., Baiocchi, M., Padula, F., Pisaniello A., Molinaro, M., Cossu, G., Levrero, M., Bouché, M. Bisperoxovanadium, a phospho-tyrosine phosphatase inhibitor, reprograms myogenic cells to acquire a pluripotent, circulating phenotype. FASEB J. 21, 3573-3583 (2007)

Key Words: satellite cells $\cdot$ gene reprogramming $\cdot$ muscle deseases $\cdot$ cell therapy
MUSCLE REGENERATION IN CASE OF INJURY OR muscular diseases is guaranteed by the activation and differentiation of satellite cells (SCs), the myogenic precursors located beneath the basal lamina of individual myofibers. SCs are characterized by the expression of the transcription factors Pax7, Msx1, and, in a subset of muscles, Pax3, of the cell surface molecules CD34, M-cadherin, and c-met and of structural proteins such as desmin (for a review see ref. 1). SCs are both able to self-renew to maintain their own pool and, upon activation, to give rise to a large number of daughter myoblasts. The use of muscle SCs in cell-mediated gene therapy approaches to correct genetic diseases, such as muscular dystrophies, is, however, limited by their rapid loss after transplantation (2). Moreover, SCs cannot cross the vessel wall, and thus systemic delivery is not possible (3). Recently, freshly isolated and homogeneous SCs have been shown to contribute to both muscle repair and SCs compartment repopulation, when grafted into $m d x$ mice (4). However, SCs expansion in culture before the engraftment greatly reduces the regenerative capacity, thus limiting their use in vivo. Although SCs are the main cellular source for muscle regeneration (5), other cell populations, including bone marrow-derived cells, bone marrow or muscle derived side population (SP), mesangioblasts, or other mesodermal-derived progenitors, can activate a myogenic program $(3,6-9)$. In most cases, the number of these cells that can be isolated from adult tissues is limited, in vitro expansion is problematic, and their actual myogenic potential is variable and possibly due to fusion, rather than transdifferentiation $(10,11)$.

\footnotetext{
${ }^{1}$ These authors contributed equally to this work.

${ }^{2}$ Present address: The Burnham Institute, La Jolla, CA, USA.

${ }^{3}$ Correspondence: Department of Histology and Med. Embr., Univ. of Rome "La Sapienza," Via A. Scarpa 14, 00161

Rome, Italy. E-mail: marina.bouche@uniroma1.it doi: $10.1096 /$ fj.06-7454com
} 
Committed and even terminally differentiated cells, as well as established cell lines, can dedifferentiate and/or transdifferentiate upon ectopic expression of specific genes. Myoblasts can be converted into physiologically active neurons through the activation of neuronal differentiation genes (12). Surprisingly, terminally differentiated myotubes can be induced to partially dedifferentiate by the expression of viral oncoproteins or of the homeobox protein msx1 $(13,14)$. More recently, bone marrow stromal cells have been shown to differentiate, upon ectopic expression of NICD, into various cell types in vivo (15). Thus, reprogramming of gene expression in committed cells might be exploited to develop innovative cell therapy strategies. Ideally, the differentiation program should be inhibited in a reversible manner to allow the cells to redifferentiate when placed in the right microenvironment. Pharmacological manipulation of signaling pathways and downstream transcription factors known to inhibit myogenic differentiation could be a reasonable alternative to the ectopic expression of a given gene and would ensure the reversibility by simple removal of the drug.

NF-кB and AP1 transcriptional activities are known to be rapidly down-regulated when muscle cells are induced to differentiate (16), whereas forced NF-кB and/or AP1 activity inhibits myogenesis through the regulation of cyclin D1 and/or of MyoD and myogenin $(17,18)$. In this study, we tested the ability of bisperoxovanadium $(\mathrm{BpV})$, a protein tyrosine phosphatase (PTP) inhibitor known to activate both NF-кB and AP1 signaling, to generate, from committed myoblasts, multipotent cell populations suitable for gene-cell therapy applications.

\section{MATERIALS AND METHODS}

\section{Cell cultures}

Muscle cell cultures

C2C12 cells, a mouse satellite cell-derived cell line (19), were grown in growing medium (GM) [Dulbecco's modified Eagle's medium (DMEM) supplemented with $10 \%$ fetal calf serum (FCS)]; to induce differentiation, the medium was replaced with differentiation medium (DM) [DMEM supplemented with $2 \%$ horse serum (HS), as described in ref. 20]. Primary mouse satellite cells (MSC) were prepared from 1-2 wk postnatal mouse limbs as described previously (21). The cells were grown in DMEM supplemented with 20\% HS and $5 \%$ chick embryo extract (EE). To induce differentiation, the cells were shifted to DMEM supplemented with 5\% HS and $1.25 \% \mathrm{EE}$ for $3-5$ days. In both cases, $\mathrm{BpV}(10 \mu \mathrm{M})$ was added upon shifting into DM.

\section{Hematopoietic colony assay}

C2C12 cells $\left(10^{3}\right.$ cells $/ 35 \mathrm{~mm}$ dish $)$ were cultured in a methylcellulose medium for colony assay of murine cells (MethoCult, Stem Cell Technologies, Inc., Vancouver, Canada) and then cultured for 4-5 days.

\section{Coculture with cardiomyocytes}

Neonatal cardiac myocytes were prepared as described previously (22); $10^{4}$ GFP-C2C12 cells $/ 35 \mathrm{~mm}$ tissue culture dish were seeded on the cardiomyocytes monolayer and cultured for additional 5 days in DM.

\section{Cell transfections and reporter gene assays}

Transfection of C2C12 cells and luciferase reporter assays were performed as described previously (20). NF-кBLuc and AP1Luc were purchased from Promega (Madison, WI, USA). The pRSV-p65 expression vector was previously described (23); the p50 $\Delta$ SP (NF-кBp50 dominant negative) was provided by Dr. P. M. Khavari (24). Previous studies demonstrated that exogenous expression of p50 $\Delta \mathrm{SP}$ resulted in inhibition of transcriptional inducibility of the target genes by NF-кB (25).

\section{Cell fractionation, immunoprecipitation, and immunoblotting}

For cell fractionation, C2C12 cells were collected, suspended in lysis buffer (20 mM HEPES, pH 7.5, $10 \mathrm{mM}$ $\mathrm{NaCl}$, phosphatase and protease inhibitors), and incubated 15 min. on ice. Nuclear fractions were obtained by centrifugation. Protein concentrations of both cytoplasmic and nuclear fractions were equalized, and SDS sample buffer was added to $1 \times$ final concentration. Immunoprecipitation and immunoblotting were performed as previously described (26). The following antibodies were used: anti-p65 (Transduction Laboratories, San Jose, CA, USA), anti-PhTyr (Cell Signaling, Danvers, MA, USA), anti-IкB $\alpha$, anti-PhSer-32 ІкB $\alpha$, antic-jun, anti-Ph-Ser-63 c-jun, and anti-p50 (clone C-19; all from Santa Cruz Biotechnology, Santa Cruz, CA, USA).

\section{RNA preparation and reverse transcriptase-polymerase chain reaction (RT-PCR) analysis}

Total RNA extraction and cDNA synthesis were done as described previously (21). The following PCR protocol was applied for all primer sets: $95^{\circ} \mathrm{C}$ for $5 \mathrm{~min}$, followed by 30 cycles of PCR $\left(1 \mathrm{~min}\right.$ at $95^{\circ} \mathrm{C}, 1 \mathrm{~min}$ at annealing temperature, 2 min at $72^{\circ} \mathrm{C}$ ), and a final 7 min extension step at $72^{\circ} \mathrm{C}$. PCR products were separated on $1 \%$ agarose gel containing ethidium bromide. The following primers were used for PCR amplifications: $\beta$-actin: fw ATGCCTCTGGTCGTACCACAGGCATTG, rev TTGCTGATCCACATCTGCTGGAAGGTG (expected band $649 \mathrm{bp}$ ); MyoD: fw GAGCAAAGTGAATGAGGCCTT, rev CACTGTAGTAGGCGGTGTCGT (expected band $330 \mathrm{bp})$; myogenin: fw AGTGAATGCAACTCCCACAG, rev TCAGAAGAGGATGCTCTCTGC (expected band $450 \mathrm{bp}$ ); Myf-5: fw TGCCATCCGCTACATTGAGAG, rev CCGGGGTAGCAGGCTGTGAGTTG (expected band $370 \mathrm{bp}$ ); Pax-3: fw AGGAGGCGGATCTAGAAAGGAAG, rev TGTGGAATAGACGTGGGCTGGTA (expected band 450 bp); Pax-7: fw TACCAGGAGACCGGGTCCATC, rev TCCGAACTTGATTCTGAGC (expected band $236 \mathrm{bp}$ ); alternatively, a different pair of primers was used for Pax 7 (which gave the same results): fw CTCCCGTCAGCTCCGTGTTTCTCA, rev ATGTCCGGGTAGTGGGTCCTCTCG (expected band $500 \mathrm{bp}$ ); PCNA: fw TCCTTGGTACAGCTTACT, rev TGCTAAGGTGTCTGCATT (expected band $165 \mathrm{bp}$ ); cyclin D1: fw GTGCCATCCATGCGGAA, rev GGATGGTCTGCTTGTTCTCA (expected band 362 bp); Sca-1: fw GATTCTCAAACAAGGAAAGTA, rev GACTGAGCTCAGGCTGAACAG (expected band 200 bp); c-Met: fw GAATGTCGTCCTACACGGCG, rev 
CACTACACAGTCAGGACACTGC (expected band $370 \mathrm{bp}$ ); ALP: fw GCCCTCTCCAAGACATATA, rev CCATGATCACGTCGATATCC (expected band 372 bp); osteocalcin: fw AAGCAGGAGGGCAATAAGGT, rev AGCTGCTGTGACATCCATAC (expected band $292 \mathrm{bp}$ ); collagen 1A2: fw GCAATCGGGATCAGTACGAA, rev CTTTCACGCCTTTGAAGCCA (expected band $484 \mathrm{bp}$ ); $C b f a$ 1: fw CCGCACGACAACCGCACCAT, rev CGCTCCGGCCCACAAATCTC (expected band $289 \mathrm{bp}$ ); MITF: fw ACCATCAGCAACTCCTGTCC, rev TCTTGCTTGATGATCCGATTC (expected band 450 bp); MMP9: fw CCTGTGTGTTCCCGTTCATCT, rev CGCTGGAATGATCTAAGCCCA (expected band $380 \mathrm{bp}$ ); IL3-R $\alpha$ : fw TACCACATCCAGATGGAACC, rev TACCACATCCAGATGGAACC (expected band 428 bp); GM-CSFR $\alpha$ : fw AACGTGACTGACAGGAAGG， rev TGTGTGTGCTGGCTGTTAAGG (expected band $454 \mathrm{bp}$ ); Bpcr 1: fw CCATAGCCACAGGCCAAAGT, rev GGGCCACATGATTCTTCCAC (expected band $330 \mathrm{bp}$ ); MDRla: fw CCCATCATTGCGATAGCTGG, rev TCCAACATATTCGGCTTTAGGC (expected band $500 \mathrm{bp}$ ); MDR1b: fw TGCTTATGGATCCCAGAGTGAC, rev TTGGTGAGGATCTCTCCGGCT (expected band 430 bp); $\alpha S G:$ fw TCGAGACAGTTTTGACACCACTAGA, rev GCTGCGCACCAGGAACTC. Quantitative real-time PCR was carried out as described previously (27).

\section{Histochemical and immunofluorescence analyses}

Alkaline phosphatase (ALP) or tartrate-resistant acid phosphatase (TRAP) activities were assayed on fixed cells using the ALP substrate or the leukocyte acid phosphatase reagent, respectively (both from Sigma-Aldrich, St. Louis, MO, USA), according to manufacturer's instructions. Immunofluorescence on cells or muscle cryosections was performed as described previously (20). The following primary antibodies were used: anti-sarcomeric myosin heavy chains MF20 (21); anti-cardiac troponin I (cTnI; Covance, Princeton, NJ, USA); anti-laminin (Sigma-Aldrich); anti-c-kit (BD Biosciences, San Jose, CA, USA), anti-MyoD (Dako, Glostrup, Denmark); anti- $\alpha$ sarcoglican ( $\alpha$-SG; Novocastra, Newcastle upon Tyne, UK). Fluorochrome-labeled secondary antibodies (Sigma) and Hoechst (Fluka, Buchs, Switzerland) for nuclear staining were then used. Samples were examined in a Zeiss Axioskop 2 Plus fluorescence microscope, equipped with a CCD camera.

\section{Flow cytometry analysis}

Cells $\left(10^{6}\right)$ were incubated on ice with $1 \mu \mathrm{g}$ of the appropriate fluorochrome-labeled antibody and analyzed with a FacsStar Plus cytofluorimeter. The following antibodies were used: anti-Sca-1, -CD45, -c-kit, -CD34, -CD11b, -Gr-1, -Ter-119, and -Mac-3 (BD Biosciences). Nonspecific fluorescent emission was determined with the specific labeled isotype. For cell cycle analysis, cells were stained with propidium iodide.

\section{Intra-arterial transplantation}

BpV-treated or untreated GFP-C2C12 cells $\left(5 \times 10^{5}\right)$ were injected into the femoral artery of 2-mo-old mice, as described previously $(3,9) ; \alpha$-SG null mice $\left(\alpha \mathrm{SG}^{-/-}\right)$were kindly provided by $\mathrm{Dr}$ K. P. Campbell (28). Mice were euthanized at 3, 5, 7, or 21 days after injection; single muscles were dissected and either processed for cryosections or used for RNA preparation. All procedures were conducted in conformity with the institutional guidelines that are in compliance with national and international laws and policies.

\section{Statistical analysis}

Statistical analysis was conducted using a $t$ test. The criterion for statistical significance was $* P<0.05$.

\section{RESULTS}

\section{BpV treatment reversibly inhibits myogenic differentiation}

We first analyzed the effect of $\mathrm{BpV}$ treatment on myogenic differentiation. Subclonfluent growing C2C12 cells were placed in DM, with or without 10 $\mu \mathrm{M} \mathrm{BpV}$. Within $4-5 \mathrm{~h}$ of treatment, BpV-treated C2C12 cells acquired a round shaped morphology; moreover, many of the cells detached from the dish, without showing any features of degeneration or apoptosis (Fig. 1A). BpV-treated primary MSC, which are already round shaped, detached from the dish to a similar extent (data not shown). Long-term (48-72 h) exposure to $\mathrm{BpV}$ inhibited the formation of C2C12 and MSC multinucleated myotubes (Fig. 1A and data not shown). The inhibition of myogenic differentiation was paralleled by a sharp down-regulation of the muscle regulatory factors (MRFs) transcripts (MyoD, myf5, and myogenin) in both C2C12 cells and MSCs; it is noteworthy that to achieve an equivalent MRF down-regulation as in MSCs, C2C12 cells needed to be exposed to $\mathrm{BpV}$ for $48 \mathrm{~h}$, suggesting that the inhibition of myogenic differentiation occurs with different kinetics in the two cell populations (Fig. $1 B$ ).

To verify whether $\mathrm{BpV}$-treated cells maintained their myogenic potential, C2C12 cells and MSCs were transferred in DM with or without $10 \mu \mathrm{M} \mathrm{BpV}$; after $24 \mathrm{~h}$, the medium was replaced with fresh $\mathrm{DM}$, cultured for additional 3 days in the absence of $\mathrm{BpV}$, and analyzed for myosin expression by immunofluorescence. Parallel cultures were maintained in $\mathrm{DM}$ containing $\mathrm{BpV}$. As shown in Fig. $1 C$, while no myosin-positive cells were found when the cells were exposed to $\mathrm{BpV}$ continuously, both pretreated C2C12 cells and MSCs still differentiated into multinucleated myosin-positive myotubes, upon $\mathrm{BpV}$ removal, with a fusion rate only slightly lower than untreated cells.

\section{$\mathrm{BpV}$ treatment induces cell cycle progression}

Permanent withdrawal from the cell cycle is a prerequisite for myogenic differentiation. To verify whether the BpV-dependent blockade of the myogenic program was associated to changes in the proliferative capacity of myogenic cells, cell cycle was monitored by FACS analysis in $\mathrm{BpV}$-treated, untreated, and proliferating C2C12 cells, cultured for different periods of time (Fig. 2A-C). C2C12 cells cultured in BpV-containing DM displayed both a slower decrease in the percentage of 
A
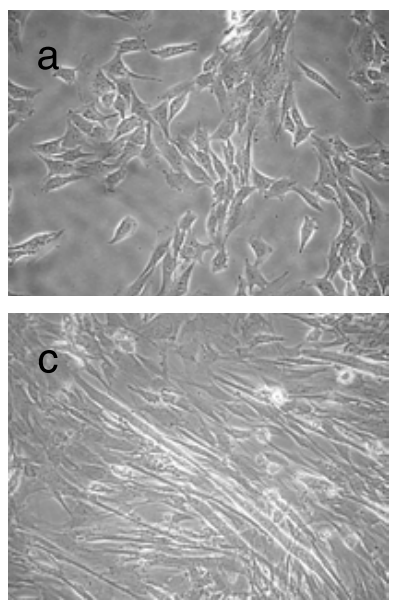

B

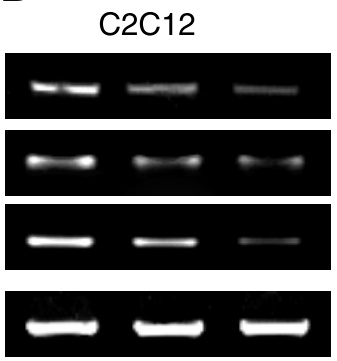

123
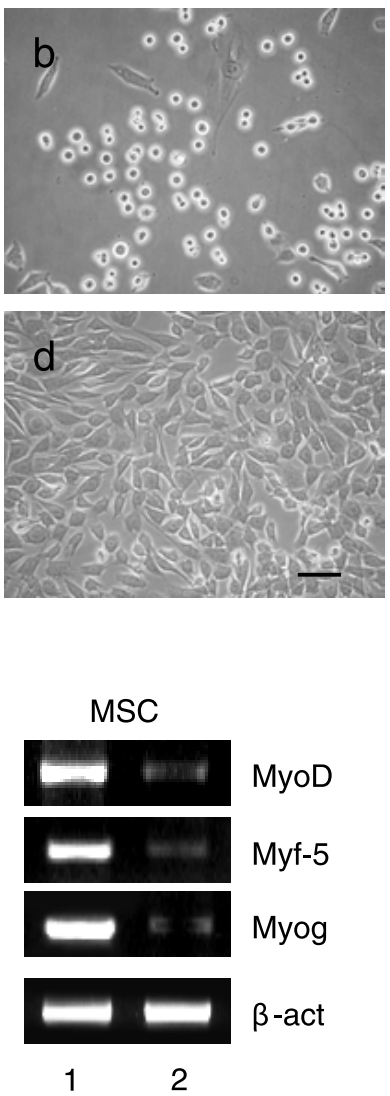

C
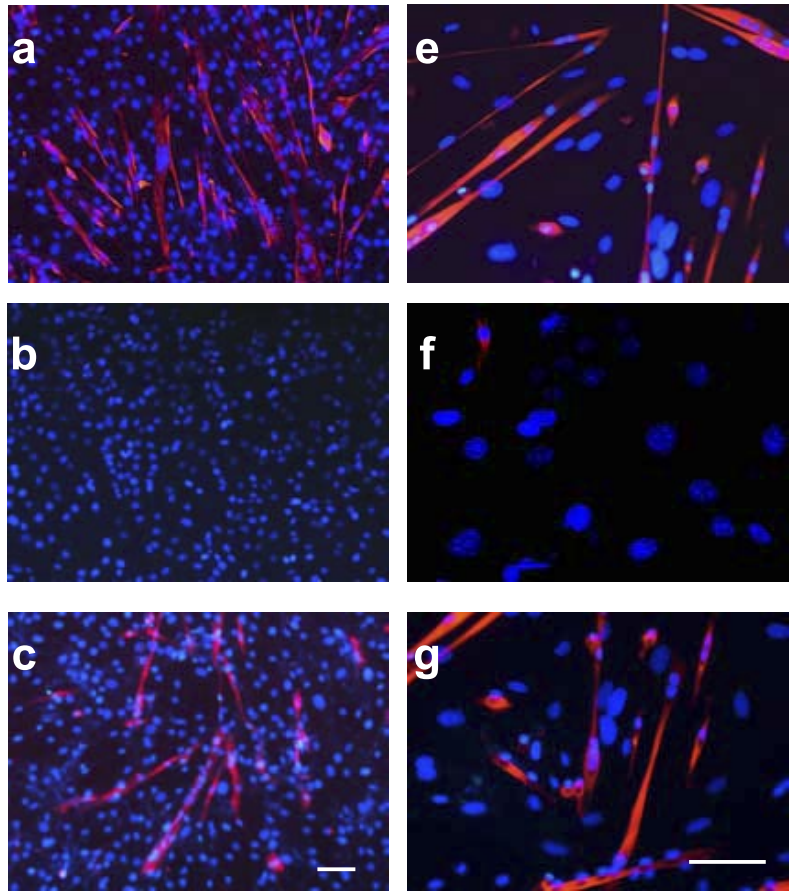

d

h

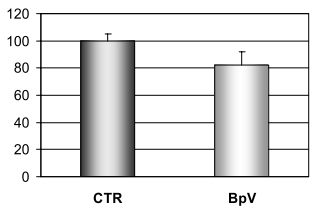

Figure 1. Effect of $\mathrm{BpV}$ on muscle cell differentiation. A) Phase contrast micrographs of C2C12 cells cultured in the absence ( $a$, $c)$ or in the presence $(b, d)$ of $10 \mu \mathrm{M} \mathrm{BpV}$ for $12(a, b)$ or $72 \mathrm{~h}(c, d)$. B) RT-PCR analysis for expression of indicated MRFs in C2C12 cells or MSC cultured in DM for $24 \mathrm{~h}$ in the absence (lane 1) or in the presence (lane 2) of $10 \mu \mathrm{M}$ BpV. RT-PCR in C2C12 cells cultured $48 \mathrm{~h}$ in the presence of $10 \mu \mathrm{M} \mathrm{BpV}$ is also shown (lane 3). C) Reversibility of BpV effects. Immunofluorescence analysis of myosin expression in C2C12 cells $(a-d)$ and MSCs $(e-h) . a, e)$ C2C12 cells and MSC, respectively, cultured for 3 days in DM. $b, f)$ C2C12 cells and MSC, respectively, cultured in BpV-containing DM for 3 days. $c$, g) C2C12 cells and MSC, respectively, cultured in $\mathrm{BpV}$-containing $\mathrm{DM}$ for $24 \mathrm{~h}$ and then for additional 3 days on $\mathrm{BpV}$ removal. Fusion rate in cells treated as in $e$ and $g$ is shown in $d$ and $h$, as percentage of nuclei in myosin-positive cells over total number of nuclei in each conditions, assuming fusion rate in untreated cells as $100 \%$ ( $d$, C2C12 cells, $h$, MSCs). Bars $=50 \mu \mathrm{m}$.

cells in the $\mathrm{S}$ phase and a slower accumulation in the percentage of cells in the $G_{1}$ phase, as compared to untreated cells, even when cultured in GM. Accordingly, RT-PCR analysis demonstrated the up-regulation of both cyclin D1, a marker of the $\mathrm{G}_{1} / \mathrm{S}$ phase transition, and PCNA, a marker of the $\mathrm{S}$ phase, in $\mathrm{BpV}$ treated C2C12 cells and MSC, as compared to untreated cells (Fig. 2, D).
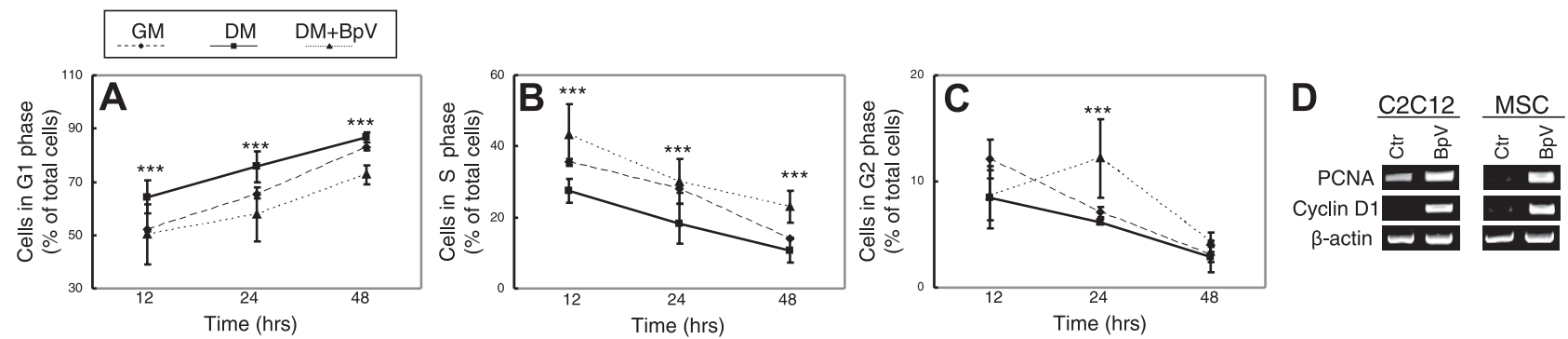

Figure 2. Effect of BpV on cell proliferation. Percentage of C2C12 cells in $\mathrm{G}_{1}(A), \mathrm{S}(B)$, or $\mathrm{G}_{2}(C)$ phase, as determined by FACS analysis of cell cycle. Cells were cultured either in DM with or without BpV, either in GM, for indicated period of time. By statistical analysis, significance was found comparing cells cultured in $\mathrm{DM}+\mathrm{BpV}$ vs. those cultured in $\mathrm{DM}(* * * P<0.0001)$. $D$, C) $=$ RT-PCR analysis of expression of PCNA and cyclin D1 in C2C12 cells and MSCs treated or not with BpV for $24 \mathrm{~h}$. expression level of $\beta$-actin was analyzed to normalize reactions. 
BpV imposes a phenotype of muscle precursor cells to $\mathrm{C} 2 \mathrm{C} 12$ and MSC

To characterize the phenotype acquired by C2C12 cells and MSCs on $\mathrm{BpV}$ treatment, we first analyzed by RT-PCR the expression of markers defining the muscle derived stem cells (MDSC; ref. 7). In contrast to MRFs, the expression of which was down-regulated in response to 24-48 $\mathrm{h} \mathrm{BpV}$ treatment (Fig. 1A), the expression of the MDSC markers Sca-1, Pax-3, and c-met were all sustained both in C2C12 cells and MSCs (Fig. 3A). Accordingly, the expression of the satellite cell marker Pax 7, which is known to be down-regulated when the cells are induced to differentiate, was also maintained by $\mathrm{BpV}$ treatment in both C2C12 and MSCs; however, longer exposure (48 $\mathrm{h}$ ) led to its down-regulation, in line with the block of the myogenic program (Fig. 3A). A characteristic shared by most MDSCs is the ability, upon Hoechst 33342 staining, to locate as an SP in the FACS profile, due to the exclusion of the dye through the activity of members of the ABC transporter superfamily [the multidrug resistance-1 (MDR1) and the breast cancer resistance protein (BCRP1)]. As shown in Fig. $3 B$, untreated C2C12 cells expressed BCRP1, and its expression was not modified by $\mathrm{BpV}$ treatment; by contrast, the expression of MDR1a and b, undetectable in untreated cells, was highly up-regulated upon $\mathrm{BpV}$ treatment. Untreated MSCs expressed MDR1b at levels that were not further increased by $\mathrm{BpV}$ treatment, whereas the expression of MDRla and BCRP1, undetectable in untreated cells, was highly up-regulated in BpV-treated MSCs. Thus, BpVtreated myogenic cells display a complete set of the ABC transporters. Accordingly, SP subpopulation increased in both C2C12 cells and MSCs exposed to $\mathrm{BpV}$, as shown by Hoechst 33342 staining (Fig. 3B). The very low percentage $(0.02 \%)$ of the total C2C12 cell population located in the SP fraction increased 4- to 5 -fold $(0.11 \%)$ in response to $\mathrm{BpV}$ treatment. As expected, a higher percentage $(0.11 \%)$ of untreated MSCs showed the SP phenotype and BpV treatment resulted in a 2-fold increase in the percentage of SP population $(0.21 \%)$.

\section{$\mathrm{BpV}$ induces stem and hematopoietic markers in C2C12 and primary SCs}

We next analyzed untreated and BpV-treated C2C12 cells for the expression of stem and hematopoietic surface markers by FACS (Fig. 3C). We found that, upon $24 \mathrm{~h} \mathrm{BpV}$ treatment, the stem cell markers Sca-1 and c-kit, already detectable in untreated cells, were significantly up-regulated; the expression of CD34, a marker of hematopoietic stem cells as well as of quiescent SCs, was further increased; the hematopoietic marker CD45 was strongly up-regulated, whereas CD11b, a monocyte/macrophage marker, displayed a modest up-regulation. Finally, the expressions of Mac-3, Gr-1, and Ter119, markers of macrophages, granulocytes, and erythrocytes, respectively, were all up-regulated. Up-regulation of Sca1, Mac3, and $\mathrm{CD} 11 \mathrm{~b}$ was also detected in BpV-treated MSCs (Fig. 3C).
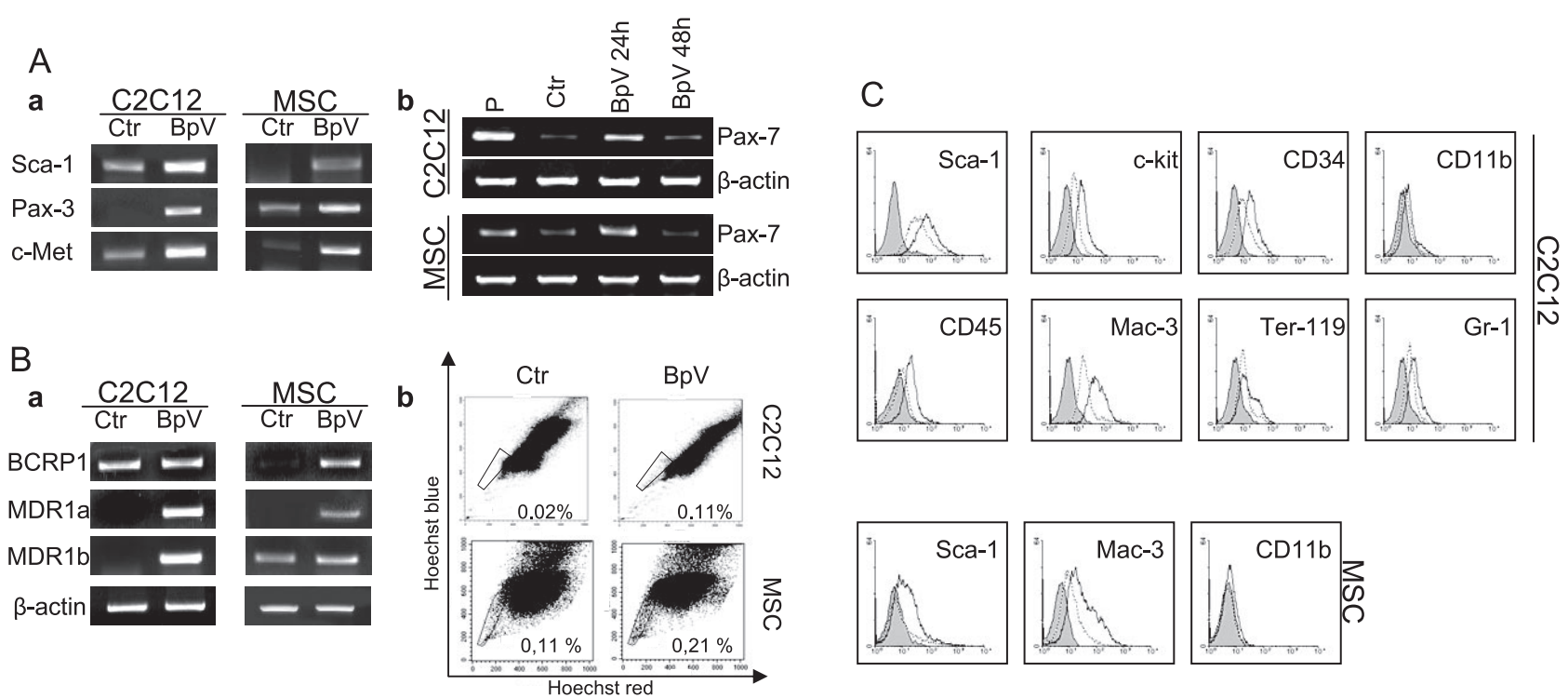

Figure 3. Effect of $\mathrm{BpV}$ on gene expression profile. Aa) RT-PCR analysis of expression of indicated markers of muscle cell precursors, in both C2C12 and MSC cells, untreated or treated with BpV for $24 \mathrm{~h}$. Ab) RT-PCR analysis of the expression of Pax7, in both C2C12 and MSC cells, untreated or treated with BpV for 24 or 48 h. Proliferating cells (cultured in GM, P) were also analyzed, as positive control. $\mathrm{Ba}$ ) RT-PCR analysis of expression of indicated SP cells markers in untreated or BpV-treated C2C12 cells and MSCs. Bb) FACS profile on Hoechst 33342 staining of C2C12 cells and MSCs untreated or BpV-treated. Population of cells located in the FACS profile as a SP is marked in each condition, and relative percentage is indicated. C) FACS-analysis of the expression of indicated stem and hematopoietic markers in untreated (dotted line) and BpV-treated (solid line) C2C12 cells and MSC, as indicated. Gray peak = control Ig. 
$\mathrm{BpV}$ treatment induces multilineage potentiality in C2C12 cells

The gene expression profile acquired by the $\mathrm{BpV}$ treated cells prompted us to evaluate whether $\mathrm{BpV}$ treated cells may acquire multilineage potentiality. We first assessed the ability to generate cells of different hematopoietic lineages. To this aim, C2C12 cells were cultured in the presence or in the absence of $10 \mu \mathrm{M}$ $\mathrm{BpV}$ for $24 \mathrm{~h}$ and then shifted to myeloid colony assay culture conditions, with or without lower $\mathrm{BpV}$ concentration $(2 \mu \mathrm{M})$. After 5 days, although both untreated and $\mathrm{BpV}$-treated cells formed colonies at similar cloning efficiency (2-3\%), untreated cells formed clones of adherent cells, while BpV-treated cells formed hematopoietic-like colonies (Fig. $\mathbf{4 A}$ ). The hematopoietic-like colonies were harvested to analyze cell morphology and gene expression. As shown in Fig. 4A, many of the cells acquired morphological features typical of myeloid cells such as monocytes, macrophages or granulocytes. Accordingly, RT-PCR analysis showed that harvested $\mathrm{BpV}$-treated cells expressed the granulocyte macrophage colony stimulating factor receptor (GM-CSFR) and the interleukin- $3 \alpha$ receptor (IL-3R $\alpha$ ), two genes normally expressed in both hematopoietic stem cells (HSCs) and common myeloid progenitors (CMPs; ref.
29; Fig. 4A). The potential of $\mathrm{BpV}$ pretreated cells to generate cells of hematopoietic origin was further confirmed by their ability to acquire an osteoclast-like phenotype, when cultured for 5 days in DM supple-

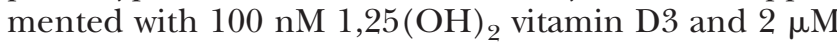
$\mathrm{BpV}$. The acid phosphatase activity (TRAP) histochemical assay showed that $>20 \%$ of the BpV-treated cells became TRAP positive (Fig. 4B). No TRAP-positive cells were detectable in untreated controls. The acquisition of an osteoclast-like phenotype on $\mathrm{BpV}$ treatment was also confirmed by the induction of two osteoclast transcripts, microphthalmia transcriptor factor (MFIT; ref. 30) and matrix metalloproteinase (MMP9; ref. 31; Fig. $4 B)$.

We next verified whether $\mathrm{BpV}$-treated cells were also capable of differentiating into a cell lineage of mesenchimal origin, such as osteoblasts. C2C12 cells, as well as MSCs, have long been known to have some multipotentiality, including a BMP2 response that can induce bone formation but only by treatment with very high concentrations of BMP2 (100-300 ng/ml; ref. 32). We tested whether $\mathrm{BpV}$ treatment may "prime" the cells to be more responsive to signals generated by the environment, as BMP2 lower concentration. To this purpose, untreated or $\mathrm{BpV}$ pretreated C2C12 cells, as above, were cultured for 5 days in DM, supplemented with 50
A
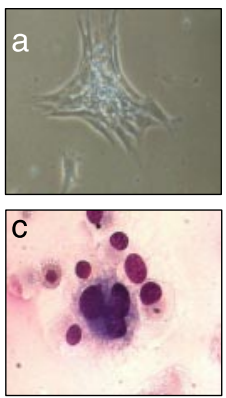

C

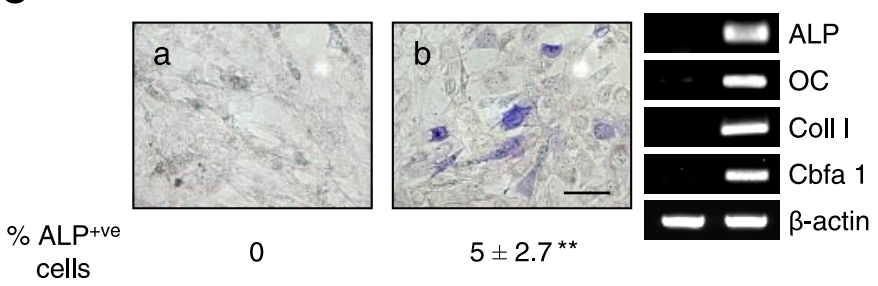

B
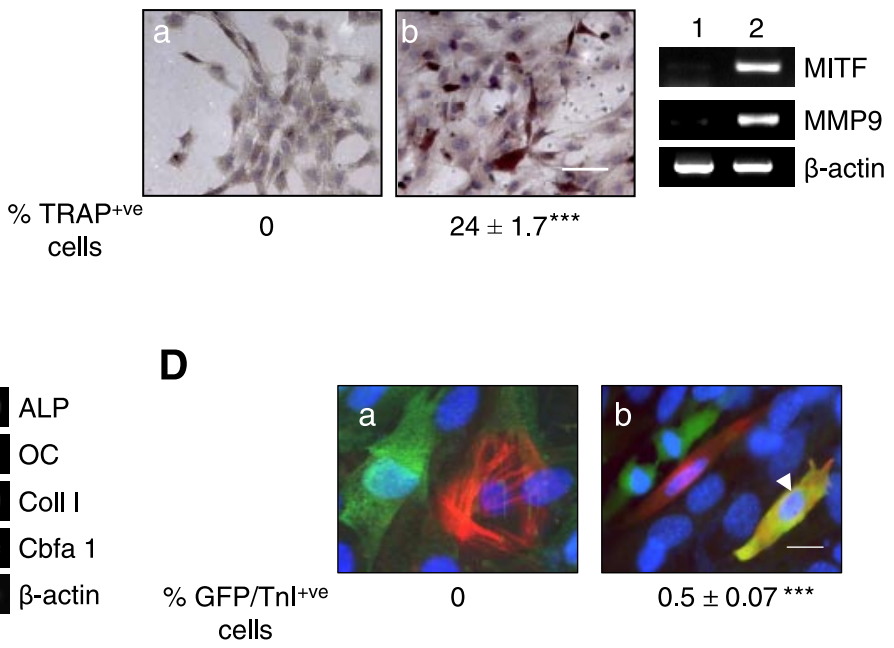

Figure 4. Effect of $\mathrm{BpV}$ on cell lineage plasticity. A) phase contrast micrographs of the colonies obtained from untreated $(a)$ and $\mathrm{BpV}$-treated (b) C2C12 cells cultured in Metho-Cult, with or without $2 \mu \mathrm{M} \mathrm{BpV;} c-e$, Giemsa staining of cells collected from colonies, as in $b$. Bars $=30 \mu \mathrm{m}$. Upper right panel $=$ RT-PCR analysis for the expression of the hemopoietic indicated markers (GM-CSFR and IL3-R $\alpha$ ); B) histochemical assay for TRAP activity in untreated $(a)$ and BpV-treated (b) C2C12 cells cultured, for 5 days, in DM containing $100 \mathrm{nM} 1,25(\mathrm{OH})_{2}$ vitaminD3. Percentage of TRAP-positive cells is also shown. Bar $=30 \mu \mathrm{m}$. Right panel = RT-PCR analysis for the expression of the osteoclast indicated markers (MFIT and MMP9). C) histochemical assay for ALP activity in untreated $(a)$ and BpV-treated $(b)$ C2C12 cells cultured in DM containing $50 \mathrm{ng} / \mathrm{ml} \mathrm{BMP2}$. Bar $=50 \mu \mathrm{m}$. Percentage of ALP-positive cells is also shown. Right panel = RT-PCR analysis for the expression of the osteoblast indicated markers (OC: osteocalcine; Coll I: collagen I). $\beta$-actin expression level was analyzed for each RNA sample to normalize the reactions. Lane $1=$ untreated; lane $2=\mathrm{BpV}$-treated cells. D) immunofluorescence analysis for the expression of cardiac troponin I (cTnI, red) in untreated $(a)$ and BpV-treated $(b)$ GFP-expressing C2C12 (green), cultured over a cardiomyocite monolayer. Arrowhead $=1$ cell coexpressing cardiac troponin I and GFP within BpV-treated cells. Percentage of GFP/cTnI coexpressing cells is also shown. Bar $=10 \mu \mathrm{m}$. Statistical analysis was conducted comparing at least three independent experiments for each assay $(* * P<0.005 ; * * * P<0.0005)$. 
$\mathrm{ng} / \mathrm{ml}$ bone morphogenetic protein 2 (BMP2) with or without $2 \mu \mathrm{M} \mathrm{BpV}$. The alkaline phosphatase activity (ALP) hystochemical assay showed that cells treated with only $50 \mathrm{ng} / \mathrm{ml}$ of BMP2 were negative for ALP activity; however, $\sim 5 \%$ of the $\mathrm{BpV}$-treated cells became ALP positive (Fig. 4C). Osteoblast conversion of $\mathrm{BpV}$ treated cells was confirmed by the induction of the transcripts for the osteoblast markers ALP, osteocalcin, type I collagen as well as the Cbfal transcriptor factor, which is considered the osteoblast master gene for its essential role in osteogenesis and osteoblast differentiation (33, 34; Fig. 4C).

Finally, we tested the ability of $\mathrm{BpV}$-treated cells to acquire a cardiomyocyte-like phenotype. To this purpose, GFP-expressing C2C12 cells, untreated or BpV pretreated, were seeded on a cardiomyocytes monolayer and cultured for additional 4 days, in DM with or without $2 \mu \mathrm{M} \mathrm{BpV}$. As shown in Fig. $4 D$, none of the $\mathrm{BpV}$-untreated GFP-expressing cells coexpressed cardiac tropononin I (cTnI, used as a cardiac marker), as detected by immunofluorescence, whereas a small proportion $(\sim 0.5 \%)$ of $\mathrm{BpV}$-treated GFP-expressing cells coexpressed cTnI.

\section{$\mathrm{BpV}$-induced reprogramming of gene expression requires $\mathrm{NF}-\mathrm{\kappa} B$ activation}

To understand the contribution of $\mathrm{BpV}$-induced signaling pathway(s) to the observed phenotype, we analyzed AP1 and NF- $\kappa$ B activity in BpV-treated muscle cells. Both pathways are known to be induced by $\mathrm{BpV}$ (35, 36) and to be strongly down-regulated during myogenic differentiation (16-17).

As shown in Fig. $\mathbf{5 A}, \mathrm{BpV}$ treatment induced a transient activation of AP1 trascriptional activity, which peaked at $6 \mathrm{~h}$, with a concomitant activation of Ser-63 c-jun phosphorylation. Moreover, $\mathrm{BpV}$ induced a rapid 2- to 3-fold activation of NF-кB-dependent transcription, which peaked by $8-9 \mathrm{~h}$ and remained above the basal activity throughout the $24 \mathrm{~h}$ of treatment. TNF- $\alpha$, a well-known NF-кB activator used as a control, induced a similar 2- to 3-fold induction that decreased below the basal activity within $15 \mathrm{~h}$. Intriguingly, we did not observe IкB kinase (IKK) complex-dependent Ser-32I $\mathrm{B} \alpha$ phosphorylation nor Iк $\mathrm{B} \alpha$ degradation in response to $\mathrm{BpV}$ treatment. By immunoprecipitation and subsequent Western blot analysis, we demonstrated that $\mathrm{BpV}$ induced both $\mathrm{I} \kappa \mathrm{B} \alpha$ tyrosine phosphorylation and p65 nuclear translocation, within 30 min of treatment (Fig. 5A). Tyr42 phosphorylation of IкB $\alpha$, followed or not (depending on the cell system) by its proteolitic degradation, has been identified recently as an "alternative" NF- $\mathrm{kB}$ activation pathway induced by a number of stimuli including the PTPase inhibitor pervanadate $(37,38)$.

Next, we sought to verify whether BpV-induced activation of NF- $\mathrm{KB}$ is required for the observed gene expression. To this aim, C2C12 cells were transfected with the p50 $\Delta$ SP expression vector, encoding the dominant negative mutant form of the p50 NF-кB subunit
A
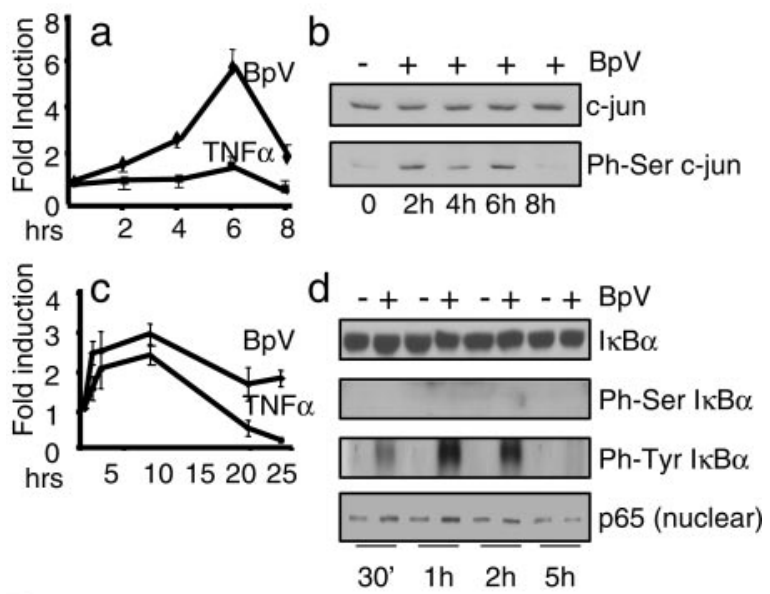

B

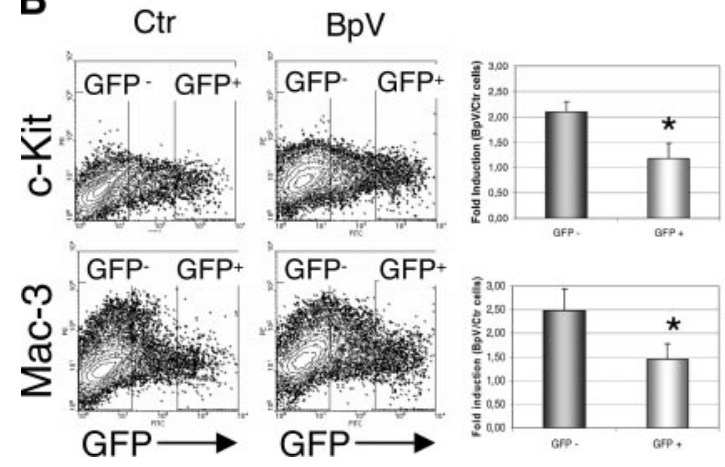

Figure 5. A) Effect of $\mathrm{BpV}$ on NF-кB and AP1 transcriptional activities. Luciferase activity assayed at different periods of time in AP1- $(a)$ or NF-kB-Luc $(c)$ transfected C2C12 cells treated or not with $10 \mu \mathrm{M} \mathrm{BpV}$ or $5 \mathrm{ng} / \mathrm{ml} \mathrm{TNF}-\alpha$. Luc activity was expressed as fold induction over untreated cells. Western blot analysis of protein extracts prepared from cells treated or not with $\mathrm{BpV}$ for different period of times, as indicated, and probed with the antic-jun or with the anti-Ph-Ser-63 c-jun in (b). In $d$, extracts were immunoprecipitated using anti-IkкB $\alpha$ antibody and blots were reacted with anti-IкB $\alpha$ or with anti-Ph-Ser-32 I $\mathrm{B} \mathrm{B} \alpha$, as well as with the anti-Ph-Tyr antibody. From parallel cultures, nuclear fractions were prepared and blot was reacted with the antip65 antibody. B) Effect of p50 0 SP expression on $\mathrm{BpV}$-induced gene expression. FACS analysis of expression of c-kit and Mac3, in C2C12 cells cotransfected with the p50 $\Delta \mathrm{SP}$ and the GFP expression vectors, and treated $(\mathrm{BpV})$ or not treated $(\mathrm{Ctr})$ with $\mathrm{BpV}$. Two populations of cells were delimitated in FACS profile: GFPnegative $\left(\mathrm{GFP}^{-}\right)$and GFP-expressing cells $\left(\mathrm{GFP}^{+}\right)$. BpVinduced expression of c-kit or Mac3 was reported as fold induction as compared to Ctr cells for each population (right histograms), as a mean ( $\pm \mathrm{SD})$ from 3 independent experiments $\left({ }^{*} P<0.03\right)$.

(24). This mutant lacks the DNA-binding domain, but it is able to form both homo- and hetero-dimers with the other members of the family ( $p 65$ and $\operatorname{RelB}$, as the major subunits expressed in C2C12 cells; ref. 39), thus functioning as a super-repressor for NF- $\mathrm{B}$ activity. A GFP expression vector was also cotransfected (at a 5:1 $\mathrm{M}$ ratio p50 $\Delta$ SP:GFP). The cells were transferred in DM with or without $10 \mu \mathrm{M} \mathrm{BpV}$. After $24 \mathrm{~h}$, the cells were FACS analyzed for the expression of c-kit and Mac3, used as molecular markers of $\mathrm{BpV}$-induced gene ex- 
pression changes. The expression of the exogenous p50 4 SP was assessed in parallel cultures by Western blot analysis, as its ability to reduce NF-кB-dependent gene activation by gene reporter assay (see Supplemental Fig. S1). The results showed that the BpV-induced $>2$-fold c-kit expression in $\mathrm{GFP}^{-}$cells was significantly reduced in $\mathrm{GFP}^{+} \Delta \mathrm{p} 50$-transfected cells (Fig. $5 B$ ); similarly, p50 $\Delta \mathrm{SP}$ mutant expression prevented the 3-fold Mac3 induction by $\mathrm{BpV}$ in the $\mathrm{GFP}^{+}$cell population (Fig. $5 B$ ). Parallel cultures were analyzed for morphology and a significant $40 \%$ reduction in cells acquiring round shape morphology was observed (not shown).

\section{BpV-treated muscle cells acquire the phenotype of a circulating progenitor}

Finally, we sought to verify whether the gene expression profile and the multipotentiality of $\mathrm{BpV}$-treated cells might also be associated with the acquisition of the phenotype of circulating progenitor, which could be delivered systemically and colonize different tissues. To this purpose, $5 \times 10^{5}$ GFP-expressing C2C12 cells, untreated or treated with $\mathrm{BpV}$ for $24 \mathrm{~h}$, were injected into the femoralis artery of $\alpha \mathrm{SG}^{-/-}$mice (3). These mice represent a model for muscular dystrophy, in which degenerating muscle fibers are continuously replaced by muscle cell precursors. Three days after intra-arterial transplantation, very few untreated GFPpositive mono-nucleated cells were observed, restricted within very damaged areas of the skeletal muscle tissue (data not shown). By contrast, when BpV-treated cells were transplanted, a large number of clustered GFPexpressing mononucleated cells were observed, most of which expressed c-Kit (Fig. 6A-C) but not MyoD (not shown). Although with variability among different microscopic fields, hundreds of donor cells could be detected. By day 5 , an average of five to six GFP-positive mono-nucleated cells/micro- field were observed, spread throughout the muscle, mostly in the interstitial space (Fig. $6 D, G$ ). By day 7 , some of these cells (5-10\%) could be detected that now expressed MyoD, indicating the activation of a myogenic differentiation program (Fig. 6E). By day 21, many fibers (82 $\pm 17 /$ cross sectional area) of the transplanted tibialis anterior (TA) expressed $\alpha \mathrm{SG}$ (an example is shown in Fig. $6 F$ ). Quantitative RT-PCR analysis showed that a significant recover of $\alpha \mathrm{SG}$ expression was detectable in the intraarterially transplanted TA (Fig. 6H). Untreated C2C12 cells did not give rise to $\alpha \mathrm{SG}$ positive fibers when transplanted intra-arterially (not shown). These results demonstrate that $\mathrm{BpV}$ treatment significantly enhances the ability of C2C12 cells to circulate, to cross the vessel wall, and consequently, to contribute to muscle regeneration.

\section{DISCUSSION}

In this study, we demonstrated that myogenic cells treated with the PTP inhibitor $\mathrm{BpV}$ acquire functional plasticity with the ability, when cultured in the appropriate conditions, to commit toward phenotypes belonging to distinct lineages; to colonize, via arterial circulation, skeletal muscle; and, finally, to contribute to muscle regeneration.

The feasibility of reprogramming gene expression and reverting already committed cells into a pluripotent state by the ectopic expression of specific genes is supported by a number of observations $(12,14,15,40)$. Cell fate can be changed upon exposure to nuclear and cytoplasmic extracts from cells of different origin (41, 42 ) or by cell fusion (43). Certain extracellular signals also exert similar effects: FGF2 induces oligodendrocyte precursor cells to revert to multipotential neural stem cells (44), whereas the SP subset within C2C12 muscle cells is expanded upon exposure to FGF6 (45). Differently from models that require the ectopic expression of a given gene, the use of cell surface receptor ligands, or pharmacological compounds can induce a reversible blockade of the differentiation program, thus allowing treated cells to redifferentiate when placed in the right microenvironment.

We show here that $\mathrm{BpV}$-treated myoblasts acquire a round shape morphology and an anchorage-independent phenotype, inhibiting myogenic differentiation. More importantly, BpV-dependent inhibition of differentiation is reversible, as myoblasts (both C2C12 and MSC cells) recover their myogenic potential on removal of the drug. BpV-treated cells do not arrest, nor differentiate, but continue to divide, though cultured in DM. Importantly, longer exposure to $10 \mu \mathrm{M} \mathrm{BpV}$ $(>48-72 \mathrm{~h})$ results, in agreement with its reported anti-neoplastic activity (20), in cell death. BpV effects on muscle cells proliferation and differentiation can be explained by its ability to prevent the down-regulation of NF- $\mathrm{B}$ and AP1 transcriptional activity. Accordingly, cyclin D1 expression, the transcription of which is known to be regulated by NF- $\mathrm{B}$ in proliferating myoblasts (17), is up-regulated in BpV-treated myoblasts cultured in DM. TNF- $\alpha$, which interferes with NF-кB and AP1 down-regulation, also blocks myogenic differentiation, but its effect is not reversible, possibly due to the concomitant degradation of myogenic transcripts (18). In addition, BpV-dependent NF- $\mathrm{B}$ activation, differently from TNF- $\alpha$, involves an alternative activation pathway that is mediated by Tyr42-IкB $\alpha$ phosphorylation and NF-кB subunits nuclear translocation without IкB $\alpha$ degradation. Further experiments will be needed to precisely define the molecular mechanisms underlying the selectivity of $\mathrm{BpV}$ activities in myoblasts and the relative contribution of the $\mathrm{BpV}$-induced signaling pathways. However, according to the results obtained with the p50 $\Delta$ SP dominant negative mutant, we provide evidence that NF- $\mathrm{B}$ signaling and transcription activity are indeed required for $\mathrm{BpV}$-dependent reprogramming of gene expression.

Our results also show that $\mathrm{BpV}$ dramatically modifies muscle cells gene expression profile: MRFs are downregulated, whereas Pax7 down-regulation is delayed as the expression of markers defining muscle precursor 

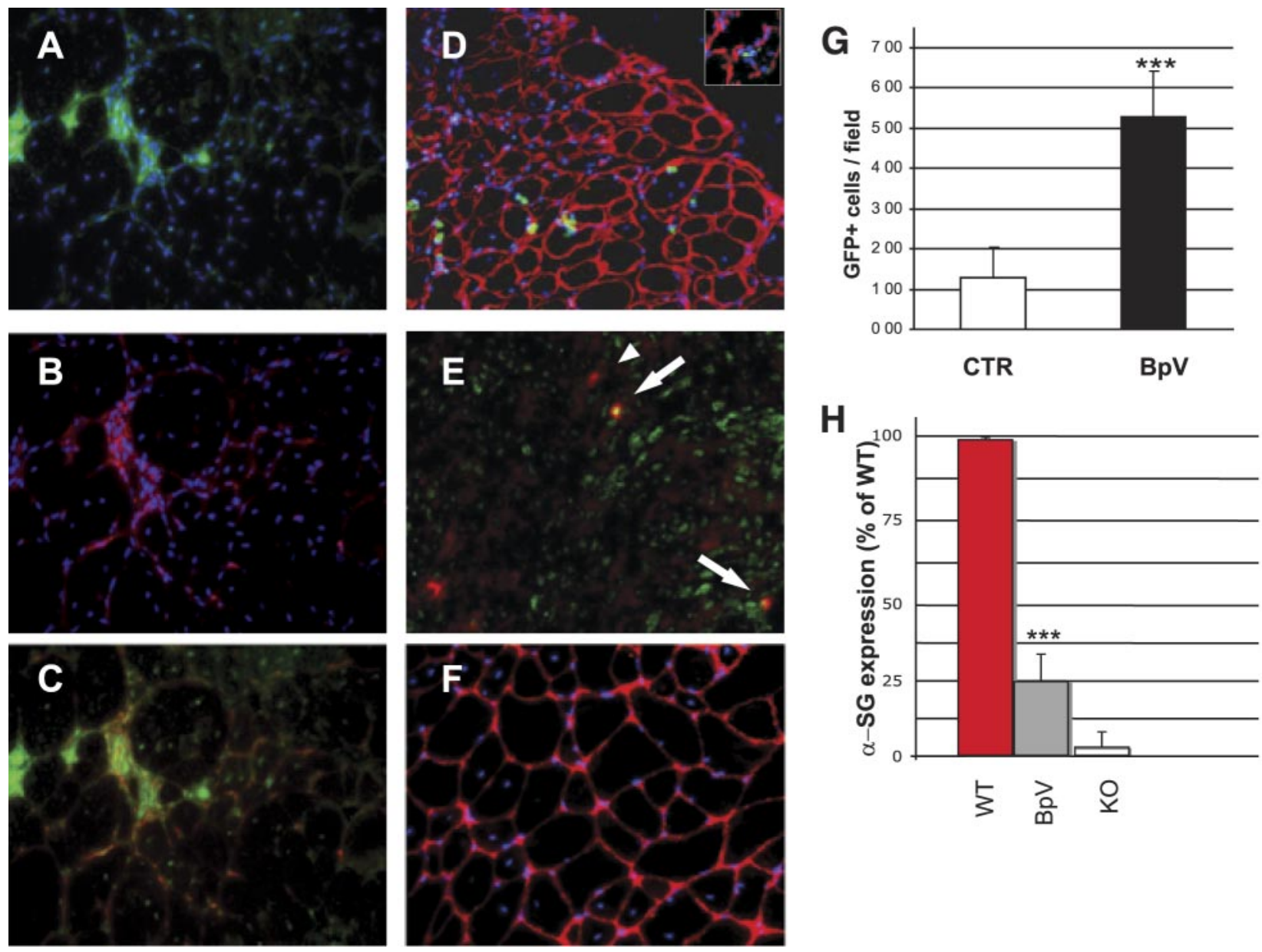

Figure 6. Intra-arterial transplantation of BpV-treated GFP-C2C12 cells in $\alpha \mathrm{SG}^{-/-}$mice. $A-C$ ) Immunofluorescence analysis of TA muscle cryo-sections from $\mathrm{SG}^{-/}$mice, transplanted, via femoral artery delivery, with BpV-treated GFP-C2C12 cells, 3 days after the injection. GFP + cells are stained in green by an anti-GFP antibody $(A)$ and c-kit expressing cells in red by an anti-cKit antibody $(B)$; merged image is shown in $C$. D) Merged immunofluorescence image of a cryo-section of a similarly transplanted TA muscle, 5 days after transplantation. GFP+ cells are stained in green and laminin in red by the anti-laminin antibody. Higher magnification is shown in inset. Number of $\mathrm{GFP}^{+}$cells/micro-field (at least 20 randomized microfield/sample) counted in muscles transplanted with either untreated (CTR) or BpV-treated (BpV) cells is reported in $G$, as mean ( \pm SE) from 3 independent experiments $(* * * P<0.001)$. E) Merged immunofluorescence image of a cryo-section of a similarly transplanted TA muscle, 7 days after transplantation. GFP + cells are stained in green and MyoD expressing cells in red. Arrow indicates two $\mathrm{GFP}+/ \mathrm{MyoD}+$ cell whereas arrowhead indicates a resident $\mathrm{GFP}^{-} / \mathrm{MyoD}^{+}$cell. F) Immunofluorescence analysis of similarly transplanted TA muscle, 21 days after transplantation. Anti- $\alpha \mathrm{SG}$ antibody stains positive fibers in red. GFP was no longer detected at this stage probably due to dilution of the protein after fusion. In all sections, nuclei are stained in blue by Hoechst. $(H)$ TA muscles from $\alpha-\mathrm{SG}^{-}{ }^{-}$mice $(n=3)$, injected via femoral artery with BpV-treated GFP-C2C12 cells (BpV), were pooled 21 days after injection and subjected to real-time PCR for the presence of $\alpha$-SG. WT and $\alpha$-SG null (KO) muscles are also shown for comparison $(* * * P<0.001$, as compared to $\mathrm{KO})$.

cells, such as, Pax-3 and c-met. Moreover, BpV treatment induces the expression of markers characteristic of adult mesenchymal or hematopoietic stem cells, such as CD34, Sca-1, and c-kit, as well as of hematopoietic lineages (CD45, CD11b, Mac-3, Gr-1, and Ter-119). Importantly, $\mathrm{BpV}$ treatment also induces the expression of a complete set of the $\mathrm{ABC}$ transporters and the expansion of the SP in both C2C12 cells and MSC. Whether similar gene expression profile is activated in all the exposed cells or whether different cell subpopulations arise upon $\mathrm{BpV}$ treatment, expressing different sets of genes, is not yet clear. Anchorage-independency appears not to reflect a cell selection, in terms of both gene expression and differentiation potential (not shown). However, altogether, the observed gene expression profile suggests that $\mathrm{BpV}$ induces a broad reprogramming of gene expression.

Accordingly, BpV-treated C2C12 cells greatly expand their plasticity and acquire the ability to differentiate along multiple lineages (hematopoietic/myeloid, including osteoclast, and cardiomyocyte). Indeed, BpV exposure lowers the BMP2 concentration required for C2C12 cells conversion into osteoblast $(24,35)$. Although BpV-promoted plasticity may not have actual applications per se, it strongly supports the conclusion that $\mathrm{BpV}$ imposes to the exposed cells the phenotype of precursor cells and "primes" the cells to be more responsive to signals generated by the environment. 
The ability to circulate, to migrate across the endothelium, and to colonize different tissues (i.e., the acquisition of a circulating progenitor phenotype) would certainly represent an highly desirable property in the perspective of developing innovative cell therapy strategies.

The results reported in this study demonstrate that, when injected systemically, BpV-treated C2C12 cells, are able to migrate outside the vessels in the presence of inflammation, as in the case of dystrophic muscle; to reach muscle tissue, with a much higher efficiency than untreated cells; and, more importantly, to contribute to muscle repair. Thus, $\mathrm{BpV}$ imposes to $\mathrm{C} 2 \mathrm{C} 12$ cells the phenotype of circulating precursors, increasing their homing toward the dystrophic muscle, while maintaining their myogenic potential, because of the reversibility of the effect. It is noteworthy that the reversion to the myogenic phenotype of $\mathrm{BpV}$-treated cells delivered by intra-arterial injections occurs much slower in vivo than in vitro, as demonstrated by the persistent expression of c-Kit and the late appearance of MyoD. Nevertheless, after 21 days many injected cells had produced $\alpha \mathrm{SG}$-expressing fibers.

The mechanism used by transplanted cells to reach muscle tissues is not clear at the moment. An attractive hypothesis would be that $\mathrm{BpV}$ treatment induces inflammatory cytokines receptors expression, the transcription of which is regulated by NF- $\mathrm{B}$ signaling in many cases, allowing circulating myogenic cells to respond to signals from the inflammatory environment of the dystrophic muscle. Sensitivity to such signals may thus improve homing, but, on the other hand, it may prevent myogenic differentiation, thus explaining the observed in vivo delay in the activation of the myogenic phenotype, as compared to the in vitro results.

In conclusion, the results reported in this study suggest that $\mathrm{BpV}$ treatment may represent a valuable approach to generate circulating precursors from committed cells, suitable for gene-cell therapy applications, as well as to study the molecular mechanism leading to genome reprogramming and "stem-ness."

We thank Dr. P. M. Khavari (Stanford University School of Medicine, Stanford, CA, USA) for the p50 $\Delta$ SP plasmid, and Dr. K. P. Campbell (University of Iowa College of Medicine, Iowa City, IA, USA) for providing the $\alpha \mathrm{SG}^{-\prime-}$ mice. We also thank Dr. M. I. Senni for excellent technical assistance, Dr. M. Pascuccio for assistance in semisolid cultures, Dr. A. Innocenzi for immunofluorescence, and Dr. S. Fera for FACS analysis. This work was supported by grants from Ministry of University \& Research, Italy (MIUR to M.B. and M.L., FIRB to M.M. and M.L.), Ministry of Health and Italian Agency of Space (to M.M.), and Duchenne Parent's Project, Italy (to G.C.).

\section{REFERENCES}

1. Palacios, D., and Puri, P. L. (2006) The epigenetic network regulating muscle development and regeneration. J. Cell Physiol. 207, 1-11

2. Beauchamp, J. R., Morgan, J. E., Pagel, C. N., and Partridge, T. A. (1999) Dynamics of myoblast transplantation reveal a discrete minority of precursors with stem cell-like properties as the myogenic source. J. Cell Biol. 144, 1113-1122

3. Sampaolesi, M., Torrente, Y., Innocenzi, A., Tonlorenzi, R., D’Antona, G., Pellegrino, M. A., Barresi, R., Bresolin, N., De Angelis, M. G., Campbell, K. P., et al. (2003) Cell therapy of alpha-sarcoglycan null dystrophic mice through intra-arterial delivery of mesoangioblasts. Science 301, 487-492

4. Montarras, D., Morgan, J., Collins, C., Relaix, F., Zaffran, S., Cumano, A., Partridge, T., and Buckingham, M. (2005) Direct isolation of satellite cells for skeletal muscle regeneration. Science 309, 2064-2067

5. Collins, C. A., Olsen, I., Zammit, P. S., Heslop, L., Petrie, A., Partridge, T. A., and Morgan, J. E. (2005) Stem cell function, self-renewal, and behavioral heterogeneity of cells from the adult muscle satellite cell niche. Cell 122, 289-301

6. Gussoni, E., Soneoka, Y., Strickland, C. D., Buzney, E. A., Khan, M. K., Flint, A. F., Kunkel, L. M., and Mulligan, R. C. (1999) Dystrophin expression in the mdx mouse restored by stem cell transplantation. Nature 401, 390-394

7. Qu-Petersen, Z., Deasy, B., Jankowski, R., Ikezawa, M., Cummins, J., Pruchnic, R., Mytinger, J., Cao, B., Gates, C., Wernig, A., and Huard, J. (2002) Identification of a novel population of muscle stem cells in mice: potential for muscle regeneration. J. Cell Biol. 157, 851-864

8. Torrente, Y., Tremblay, J. P., Pisati, F., Belicchi, M., Rossi, B., Sironi, M., Fortunato, F., El Fahime, M., D'Angelo, M. G., et al. (2001) Intraarterial injection of muscle-derived CD34(+) Sca$1(+)$ stem cells restores dystrophin in mdx mice. J. Cell Biol. 152, 335-348

9. Dellavalle, A., Sampaolesi, M., Tonlorenzil R, Tagliafico, E., Sacchetti, B., Perani, L., Innocenzi, A., Galvez, B. G., Messina, G., Morosetti, R., et al. (2007) Pericytes of human skeletal muscle are myogenic precursors distinct from satellite cells. Nat. Cell Biol. 9, 255-267

10. Sherwood, R. I., Christensen, J. L., Conboy, I. M., Conboy, M. J., Rando, T. A., Weissman, I. L., and Wagers, A. J. (2004) Isolation of adult mouse myogenic progenitors: functional heterogeneity of cells within and engrafting skeletal muscle. Cell 119, 543-554

11. Sacco, A., Doyonnas, R., LaBarge, M. A., Hammer, M. M., Kraft, P., and Blau, H. M. (2005) IGF-I increases bone marrow contribution to adult skeletal muscle and enhances the fusion of myelomonocytic precursors. J. Cell Biol. 171, 483-492

12. Watanabe, Y., Kameoka, S., Gopalakrishnan, V., Aldape, K. D., Pan, Z. Z., Lang, F. F., and Majumder, S. (2004) Conversion of myoblasts to physiologically active neuronal phenotype. Genes Dev. 18, 889-900

13. Latella, L., Sacchi, A., and Crescenzi, M. (2000) Long-term fate of terminally differentiated skeletal muscle cells following E1Ainitiated cell cycle reactivation. Cell Death Differ. 7, 145-154

14. Odelberg, S. J., Kollhoff, A., and Keating, M. T. (2000) Dedifferentiation of mammalian myotubes induced by msx1. Cell 103, 1099-1109

15. Dezawa, M., Ishikawa, H., Itokazu, Y., Yoshihara, T., Hoshino, M., Takeda, S., Ide, C., and Nabeshima, Y. (2005) Bone marrow stromal cells generate muscle cells and repair muscle degeneration. Science 309, 314-317

16. Lehtinen, S. K., Rahkila, P., Helenius, M., Korhonen, P., and Salminen, A. (1996) Down-regulation of transcription factors AP-1, Sp-1, and NF-kappa B precedes myocyte differentiation. Biochem. Biophys. Res. Commun. 229, 36-43

17. Guttridge, D. C., Albanese, C., Reuther, J. Y., Pestell, R. G., and Baldwin, A. S., Jr. (1999) NF-kappaB controls cell growth and differentiation through transcriptional regulation of cyclin D1. Mol. Cell Biol. 19, 5785-5799

18. Guttridge, D. C., Mayo, M. W., Madrid, L. V., Wang, C. Y., and Baldwin, A. S., Jr. (2000) NF-kappaB-induced loss of MyoD messenger RNA: possible role in muscle decay and cachexia. Science 289, 2363-2366

19. Blau, H. M., Pavlath, G. K., Hardeman, E. C., Chiu, C. P., Silberstein, L., Webster, S. G., Miller, S. C., and Webster, C. (1985) Plasticity of the differentiated state. Science 230, 758-766

20. D'Andrea, M., Pisaniello, A., Serra, C., Senni, M. I., Castaldi, L., Molinaro, M., and Bouche, M. (2006) Protein kinase C theta co-operates with calcineurin in the activation of slow muscle genes in cultured myogenic cells. J. Cell Physiol. 207, 379-388

21. Pisaniello, A., Serra, C., Rossi, D., Vivarelli, E., Sorrentino, V., Molinaro, M., and Bouche, M. (2003) The block of ryanodine 
receptors selectively inhibits fetal myoblast differentiation. J. Cell Sci. 116, 1589-1597

22. Bonci, D., Cittadini, A., Latronico, M. V., Borello, U., Aycock, J. K., Drusco, A., Innocenzi, A., Follenzi, A., Lavitrano, M. Monti, M. G., et al. (2003) "Advanced" generation lentiviruses as efficient vectors for cardiomyocyte gene transduction in vitro and in vivo. Gene Ther. 10, 630-636

23. Natoli, G., Costanzo, A., Guido, F., Moretti, F., Bernardo, A., Burgio, V. L., Agresti, C., and Levrero, M. (1998) Nuclear factor $\kappa \mathrm{B}$-independent cytoprotective pathways originating at tumor necrosis factor receptor-associated factor 2. J. Biol. Chem. 273, 31262-31272

24. Seitz, C. S., Lin, Q., Deng, H., and Khavari, P. A. (1998) Alterations in NF-kappaB function in transgenic epithelial tissue demonstrate a growth inhibitory role for NF-kappaB. Proc. Natl. Acad. Sci. U. S. A. 95, 2307-2312

25. Logeat, F., Israel, N., Ten, R., Blank, V., Le Bail, O., Kourilsky, P., and Israel, A. (1991) Inhibition of transcription factors belonging to the rel/NF-kappa $\mathrm{B}$ family by a transdominant negative mutant. EMBO J. 10, 1827-1832

26. Pediconi, N., Ianari, A., Costanzo, A., Belloni, L., Gallo, R. Cimino, L., Porcellini, A., Screpanti, I., Balsano, C., Alesse, E., et al. (2003) Differential regulation of E2F1 apoptotic target genes in response to DNA damage. Nat. Cell Biol. 5, 552-558

27. Galvez, B. G., Sampaolesi, M., Brunelli, S., Covarello, D., Gavina, M., Rossi, B., Constantin, G., Torrente, Y., and Cossu, G. (2006) Complete repair of dystrophic skeletal muscle by mesoangioblasts with enhanced migration ability. J. Cell Biol. 174, 231-243

28. Duclos, F., Straub, V., Moore, S. A., Venzke, D. P., Hrstka, R. F., Crosbie, R. H., Durbeej, M., Lebakken, C. S., Ettinger, A. J., van der, M. J., et al. (1998) Progressive muscular dystrophy in alpha-sarcoglycan-deficient mice. J. Cell Biol. 142, 1461-1471

29. Miyamoto, T., Iwasaki, H., Reizis, B., Ye, M., Graf, T., Weissman, I. L., and Akashi, K. (2002) Myeloid or lymphoid promiscuity as a critical step in hematopoietic lineage commitment. Dev. Cell 3, 137-147

30. Luchin, A., Suchting, S., Merson, T., Rosol, T. J., Hume, D. A., Cassady, A. I., and Ostrowski, M. C. (2001) Genetic and physical interactions between Microphthalmia transcription factor and PU. 1 are necessary for osteoclast gene expression and differentiation. J. Biol. Chem. 276, 36703-36710

31. Delaisse, J. M., Andersen, T. L., Engsig, M. T., Henriksen, K., Troen, T., and Blavier, L. (2003) Matrix metalloproteinases (MMP) and cathepsin K contribute differently to osteoclastic activities. Microsc. Res. Tech. 61, 504-513

32. Katagiri, T., Yamaguchi, A., Komaki, M., Abe, E., Takahashi, N., Ikeda, T., Rosen, V., Wozney, J. M., Fujisawa-Sehara, A., and Suda, T. (1994) Bone morphogenetic protein-2 converts the differentiation pathway of C2C12 myoblasts into the osteoblast lineage. J. Cell Biol. 127, 1755-1766

33. Komori, T., Yagi, H., Nomura, S., Yamaguchi, A., Sasaki, K., Deguchi, K., Shimizu, Y., Bronson, R. T., Gao, Y. H., Inada, M., et al. (1997) Targeted disruption of Cbfal results in a complete lack of bone formation owing to maturational arrest of osteoblasts. Cell 89, 755-764

34. Ducy, P., Zhang, R., Geoffroy, V., Ridall, A. L., and Karsenty, G. (1997) Osf2/Cbfa1: a transcriptional activator of osteoblast differentiation. Cell 89, 747-754

35. Barat, C., and Tremblay, M. J. (2003) Treatment of human T cells with bisperoxovanadium phosphotyrosyl phosphatase inhibitors leads to activation of cyclooxygenase-2 gene. J. Biol. Chem. 278, 6992-7000

36. Ouellet, M., Roy, J., Barbeau, B., Geleziunas, R., and Tremblay, M. J. (2003) NF-kappaB induction by bisperoxovanadium compounds requires CD45, p36(LAT), PKC, and IKK activity and exhibits kinetics of activation comparable to those of TCR/ CD28 coengagement. Biochemistry 42, 8260-8271

37. Imbert, V., Rupec, R. A., Livolsi, A., Pahl, H. L., Traenckner, E. B., Mueller-Dieckmann, C., Farahifar, D., Rossi, B., Auberger, P., Baeuerle, P. A., and Peyron, J. F. (1996) Tyrosine phosphorylation of I kappa B-alpha activates NF-kappa B without proteolytic degradation of I kappa B-alpha. Cell 86, 787-798

38. Waris, G., Livolsi, A., Imbert, V., Peyron, J. F., and Siddiqui, A. (2003) Hepatitis C virus NS5A and subgenomic replicon activate NF-kappaB via tyrosine phosphorylation of IkappaBalpha and its degradation by calpain protease. J. Biol. Chem. 278, 4077840787

39. Zhou, L. Z., Johnson, A. P., and Rando, T. A. (2001) NF kappa $\mathrm{B}$ and AP-1 mediate transcriptional responses to oxidative stress in skeletal muscle cells. Free Radic. Biol. Med. 31, 1405-1416

40. Hu, E., Tontonoz, P., and Spiegelman, B. M. (1995) Transdifferentiation of myoblasts by the adipogenic transcription factors PPAR gamma and C/EBP alpha. Proc. Natl. Acad. Sci. U. S. A. 92 , 9856-9860

41. Hakelien, A. M., Landsverk, H. B., Robl, J. M., Skalhegg, B. S., and Collas, P. (2002) Reprogramming fibroblasts to express T-cell functions using cell extracts. Nat. Biotechnol. 20, 460-466

42. Taranger, C. K., Noer, A., Sorensen, A. L., Hakelien, A. M., Boquest, A. C., and Collas, P. (2005) Induction of dedifferentiation, genomewide transcriptional programming, and epigenetic reprogramming by extracts of carcinoma and embryonic stem cells. Mol. Biol. Cell 16, 5719-5735

43. Pomerantz, J., and Blau, H. M. (2004) Nuclear reprogramming: a key to stem cell function in regenerative medicine. Nat. Cell Biol. 6, 810-816

44. Kondo, T., and Raff, M. (2000) Oligodendrocyte precursor cells reprogrammed to become multipotential CNS stem cells. Science 289, 1754-1757

45. Israeli, D., Benchaouir, R., Ziaei, S., Rameau, P., Gruszczynski, C., Peltekian, E., Danos, O., and Garcia, L. (2004) FGF6 mediated expansion of a resident subset of cells with SP phenotype in the C2C12 myogenic line. J. Cell Physiol. 201, $409-419$

Received for publication October 17, 2006. Accepted for publication May 24, 2007. 